\title{
Apple Market Integration: Implications for Sustainable Agricultural Development
}

\author{
Khalid Mushtaq, Abdul Gafoor and Maula Dad
}

\begin{abstract}
In a market driven economy, price signals guide and regulate production, consumption and marketing decisions over time, form and place. Identifying the causes of price differences in interregional or spatial markets has therefore become an important economic analytical tool to understand markets better. If markets are not well integrated, price signals are distorted, which leads to an inefficient allocation of resources. Further, it may constrain sustainable agricultural development and aggravate inequitable patterns of income distribution. This paper examines the degree of spatial market integration in the regional apple markets of Pakistan using cointegration analysis and monthly wholesale price data from January, 1996 to December, 2005. Results show that apple markets are perfectly integrated and Quetta is the dominating market. The high degree of market integration observed in this case is consistent with view that apple markets in Pakistan are quite competitive and provide little justification for government intervention designed to improve competitiveness to enhance market efficiency.
\end{abstract}

JEL Classification: C22, Q13, Q18

Keywords: Market Integration, Cointegration, Apple, Pakistan

\section{Introduction}

In a market driven economy, the pricing mechanism is expected to transmit orders and directions to determine the flow of marketing activities. Pricing signals guide and regulate production, consumption and marketing decisions over time, form and place (Kohls and Uh1, 1998). Identifying the

\footnotetext{
* Assistant Professor, Lecturer and Postgraduate Student respectively in the Department of Agricultural Economics; Department of Marketing \& Agribusiness, University of Agriculture, Faisalabad, Pakistan.
} 
causes of price differences in interregional or spatial markets has therefore become an important economic analytical tool to understand markets better.

In developing economies, there are several impediments to the efficient functioning of markets, particularly agricultural commodity markets. These include insufficient transportation infrastructure, difficulties in accessing market information, government-imposed restrictions on the movement of goods between regions, government monopoly over the marketing and distribution system, and poor enforcement of anti-trust regulations that result in price fixing and oligopolistic market structures. If markets are not well-integrated, then price signals could be distorted which leads to an inefficient allocation of resources, and the marketable surplus generated by the farmers could result in depressed farm prices and diminishing income (Tahir and Riaz, 1997).

Market integration is an alternative approach to stabilize prices, allocate resources and rectify market imperfections like entrenched monopolies or monopsonies and inadequate and costly information transmission. The rectification of market imperfections smoothes the way to attain market efficiency, which in turn facilitates the attainment of agricultural development and equal distribution of income. If markets are well integrated then government can stabilize the price in one key market and rely on commercialization to produce a similar outcome in other markets. This reduces the cost of stabilization considerably. Further, farmers will not be constrained by local demand conditions.

Spatial market integration refers to co-movements or a long run relationship of prices. It is defined as the smooth transmission of price signals and information across spatially separated markets (Golleti, et al., 1995). Two trading markets are assumed integrated if price changes in one market are manifested in an identical price response in the other market (Barrett, 1996). Market integration can also be defined as a measure of the extent to which demand and supply in one location are transmitted to another (Negassa et al., 2003). To illustrate integration in two markets, consider two markets A and B. Suppose market A experiences a bad harvest while market $B$ does not. Due to the bad harvest the price will suddenly increase in market $A$. In the absence of communication flows between the two markets, the price in the market $B$ will not change. Thus markets $A$ and $B$ are completely separated and prices of the same commodity are not related. On the other hand if markets $A$ and $B$ are integrated, the commodity will flow from $B$ to $A$ and prices in market $A$ will come down. However, the price in market B will rise because of less availability of supply in B. 
In the case of widely spatially dispersed regional markets in developing countries, the nature and extent of market integration is of particular importance. The nature of optimal policies depends on the dynamics of market integration and the cost of incorrect policies can be massive (Ravallion, 1986). Much emphasis is given to area and production of apples in Pakistan, while relatively little is known about how price transmission takes place in the domestic apple market. Such information is important for apple producers and other players in the apple value chain since it affects their marketing decisions (buying and selling), which in turn affects decisions related to logistical matters and eventually profits realized. In this context, the present study aims at empirically estimating the degree of integration in apple markets of Pakistan. The paper is organized as follows: Section 2 discusses the empirical approach; Section 3 discusses the data and results; while Section 4 concludes.

\section{Empirical Methodology}

We begin by testing for the presence of unit roots in the individual time series of each model using the augmented Dickey-Fuller (ADF) test (Dickey and Fuller, 1981), both with and without a deterministic trend. The number of lags in the ADF-equation is chosen to ensure that serial correlation is absent using the Breusch-Godfrey statistic (Greene, 2000, p. 541). The $\mathrm{ADF}$ equation required for estimation by OLS is the following:

$$
\Delta Y_{t}=\alpha_{3}+\beta_{3} t+\left(\phi_{3}-1\right) Y_{t-1}+\sum_{i=1}^{k} \theta_{i} \Delta Y_{t-i}+u_{t}
$$

where $Y_{t}$ is the series under investigation, $t$ is a time trend ${ }^{1}$ and $u_{t}$ are white noise residuals. We do not know that how many lagged values of the dependent variable to include on the right-hand side of (1). There are several approaches but we use the Lagrange Multiplier (LM) test (Holden and Perman, 1994, p. 62).

If two series are integrated of the same order, Johansen's (1988) procedure can then be used to test for a long run relationship between them. The procedure is based on maximum likelihood estimation of the vector error correction model (VECM):

$$
\Delta z_{t}=\delta+\Gamma_{1} \Delta z_{t-1}+\Gamma_{2} \Delta z_{t-2}+\cdots+\Gamma_{p-1} \Delta z_{t-p+1}+\pi z_{t-p}+\Psi x_{t}+u_{t}
$$

\footnotetext{
${ }^{1}$ The rationale for having a trend variable in the model is that most of the series are trended over time. So it is important to test the series for unit roots having a stochastic trend against the alternative of trend stationarity.
} 
where $Z_{t}$ is a vector of $I(1)$ endogenous variables, $\Delta z_{t}=Z_{t}-Z_{t-1}, x_{t}$ is vector of $I(0)$ exogenous variables, and $\pi$ and $\Gamma_{i}$ are $(n \times n)$ matrices of parameters with $\Gamma_{\mathrm{i}}=-\left(\mathrm{I}-\mathrm{A}_{1}-\mathrm{A}_{2}-\ldots-\mathrm{A}_{\mathrm{i}}\right), \quad(\mathrm{i}=1, \ldots, \mathrm{k}-1)$, and $\pi=\mathrm{I}-\pi_{1}-\pi_{2}-\ldots-\pi_{\mathrm{k}}$. This specification provides information about the short-run and long-run adjustments to the changes in $z_{\mathrm{t}}$ through the estimates of $\hat{\Gamma}_{i}$ and $\hat{\pi}$ respectively. The term $\pi \mathrm{z}_{\mathrm{t}-\mathrm{k}}$ provides information about the long-run equilibrium relationship between the variables in $\mathbf{z}_{\mathbf{t}}$. Information about the number of cointegrating relationships among the variables in $z_{t}$ is given by the rank of the $\pi$-matrix: if $\pi$ is of reduced rank, the model is subject to a unit root; and if $0<\mathrm{r}<\mathrm{n}$, where $\mathrm{r}$ is the rank of $\pi, \pi$ can be decomposed into two $(\mathrm{n} \times \mathrm{r})$ matrices $\alpha$ and $\beta$, such that $\pi=\alpha \beta^{\prime}$ where $\beta^{\prime} z_{t}$ is stationary. Here, $\alpha$ is the error correction term and measures the speed of adjustment in $\Delta \mathrm{z}_{\mathrm{t}}$ and $\beta$ contains $r$ distinct cointegrating vectors, that is the cointegrating relationships between the non-stationary variables. Johansen (1988) uses the reduced rank regression procedure to estimate the $\alpha$ - and $\beta$-matrices and the trace test statistic is used to test the null hypothesis of at most $r$ cointegrating vectors against the alternative that it is greater than $r$.

\section{Data and Results}

Monthly wholesale price (Rs. 40/ kgs) data from January, 1996 to December, 2005 of apples (120 observations) for the post-liberalization period in logarithmic form will be used. The study analyzes price transmission in nine selected apple markets in Pakistan. The markets included in this study are Quetta, Peshawar, Lahore, Faisalabad, Multan, Sargodha, Gujranwala, Karachi, and Hyderabad. The criterion for selecting these markets is based on net market positions (surplus or deficit area), geographical distribution, data availability and the volume of trade or the importance of the market to the national apple trade flow.

Table-1 reports the unit root results using ADF tests both with and without a linear trend. The null hypothesis is that the variable observed has a unit root against the alternative that it does not. Both models indicate that of a null of unit root cannot be rejected for all price series, as the absolute values of the ADF statistics are well below the $95 \%$ critical value of the test statistics. Thus we conclude that all the price series are non-stationary. 
Table-1: Unit Root Tests Results

\begin{tabular}{lcc}
\hline Prices & $\begin{array}{c}\text { Non-Trended } \\
\text { Model }\end{array}$ & Trended Model \\
\hline Quetta & -2.20 & -3.06 \\
Karachi & -2.10 & -3.15 \\
Hyderabad & -2.41 & -3.22 \\
Peshawar & -2.43 & -3.19 \\
Lahore & -2.74 & -3.40 \\
Faisalabad & -1.47 & -2.48 \\
Multan & -1.54 & -2.64 \\
Sargodha & -1.15 & -2.52 \\
Gujranwala & -1.43 & -3.10 \\
CV (95\% Confidence Level) & -2.88 & -3.45 \\
\hline
\end{tabular}

After testing for a unit root, the next step is to test for cointegration. Johansen's procedure has been applied to apple prices. The first step in Johansen's procedure is the selection of the order of the Vector Auto Regression (VAR) model. We use the LR-statistic ${ }^{2}$, adjusted for small samples (Sims, 1980), to test the null hypothesis that the order of the VAR is $\mathrm{k}$ against the alternative that it is four where $\mathrm{k}=0,1, \ldots, 4$ and for all cases, $\mathrm{k}=1$. The second step in the Johansen procedure is to test for the presence and number of cointegrating vectors among the series in each model. Table- 2 presents Johansen's cointegration results. The trace test results show there are seven cointegrating vectors and two common trends at the 95\% confidence level because first seven statistical values of trace statistics $(445.489,338.524,250.985,168.785,104.359,65.768,37.674)$ are greater than their respective $95 \%$ critical values $(203.96,166.12,132.45,102.56$, $75.98,53.48,34.87)$ whereas the remaining two statistical values of trace statistics $(14.992,2.208)$ are less than their respective $95 \%$ critical values i.e. $20.18,9.16$. The trace test results suggest that these nine price series are strongly cointegrated and converge to long run equilibrium in the sense that the Pakistani apple market system is stationary in seven directions and non-stationary in two directions. In other words, seven prices can be expressed in terms of the other two prices, meaning that prices in nine apple markets are fully cointegrated as the law of one price (LOP) holds.

\footnotetext{
${ }^{2}$ We also tried the Schwarz Bayesian Criterion (SBC) and Akaike information Criterion (AIC). Both SBC and AIC selects lag length one and three respectively. To avoid overparameterization, we choose one as the lag length (Pesaran and Pesaran, 1987).
} 
Table-2: Cointegration Results - Trace Statistics

\begin{tabular}{lcccc}
\hline Equation Tested & Null & Alternative & Statistics & 95\% C V \\
\hline Quetta, Karachi, & $\mathrm{r}=0$ & $\mathrm{r}=1$ & 445.489 & 203.96 \\
Lahore, Hyderabad, & $\mathrm{r}<=1$ & $\mathrm{r}=2$ & 338.524 & 166.12 \\
Peshawar, Faisalabad, & $\mathrm{r}<=2$ & $\mathrm{r}=3$ & 250.985 & 132.45 \\
Multan, Sargodha, & $\mathrm{r}==3$ & $\mathrm{r}=4$ & 168.785 & 102.56 \\
Gujranwala & $\mathrm{r}<=3.959$ & 75.98 \\
& $\mathrm{r}<=4$ & $\mathrm{r}=5$ & 104.359 & 53.48 \\
& $\mathrm{r}<=5$ & $\mathrm{r}=6$ & 65.768 & 34.87 \\
& $\mathrm{r}<=6$ & $\mathrm{r}=7$ & 37.674 & 20.18 \\
& $\mathrm{r}<=7$ & $\mathrm{r}=8$ & 14.992 & 9.16 \\
\hline
\end{tabular}

It suggests that even though the regional markets are geographically dispersed and spatially segmented, spatial pricing relationships reveal that the prices are linked together indicating that all the apple exchange locations are in the same economic market. First, the relationship among all nine markets has been checked. Next, the pair-wise relationship between the markets will be analyzed. We take the Quetta market as a main apple market and check the relationship of all other markets with it. Table-3 reports the pair-wise cointegrating relationships between the markets. The results of pair-wise cointegrating relationships indicates that the Karachi, Hyderabad, Peshawar, Lahore, Faisalabad and Multan markets are strongly integrated with the Quetta apple market, in the sense that these markets have two cointegrating vectors as their estimated trace statistics are greater than the $95 \%$ critical values while the Sargodha and Gujranwala markets were integrated but not strongly with the Quetta market as they have one cointegrating vector. 
Table-3: Pair-wise Cointegration Results --- Trace Statistics

\begin{tabular}{llll}
\hline Equation Tested & Null & Alternative & \multicolumn{1}{c}{ Statistics } \\
\hline Quetta - Karachi & $\mathrm{r}=0$ & $\mathrm{r} \geq 1$ & $24.48(20.18)$ \\
& $\mathrm{r} \leq 1$ & $\mathrm{r} \geq 2$ & $12.68(9.16)$ \\
Quetta - Hyderabad & $\mathrm{r}=0$ & $\mathrm{r} \geq 1$ & $72.08(20.18)$ \\
& $\mathrm{r} \leq 1$ & $\mathrm{r} \geq 2$ & $18.58(9.16)$ \\
Quetta - Peshawar & $\mathrm{r}=0$ & $\mathrm{r} \geq 1$ & $35.17(20.18)$ \\
& $\mathrm{r} \leq 1$ & $\mathrm{r} \geq 2$ & $10.92(9.16)$ \\
Quetta - Lahore & $\mathrm{r}=0$ & $\mathrm{r} \geq 1$ & $51.42(20.18)$ \\
& $\mathrm{r} \leq 1$ & $\mathrm{r} \geq 2$ & $12.82(9.16)$ \\
Quetta - Faisalabad & $\mathrm{r}=0$ & $\mathrm{r} \geq 1$ & $39.54(20.18)$ \\
& $\mathrm{r} \leq 1$ & $\mathrm{r} \geq 2$ & $11.30(9.16)$ \\
Quetta - Multan & $\mathrm{r}=0$ & $\mathrm{r} \geq 1$ & $57.19(20.18)$ \\
& $\mathrm{r} \leq 1$ & $\mathrm{r} \geq 2$ & $11.23(9.16)$ \\
Quetta - Sargodha & $\mathrm{r}=0$ & $\mathrm{r} \geq 1$ & $23.36(20.18)$ \\
& $\mathrm{r} \leq 1$ & $\mathrm{r} \geq 2$ & $1.81(9.16)$ \\
Quetta - Gujranwala & $\mathrm{r}=0$ & $\mathrm{r} \geq 1$ & $25.01(20.18)$ \\
& $\mathrm{r} \leq 1$ & $\mathrm{r} \geq 2$ & $2.67(9.16)$ \\
\hline
\end{tabular}

Note: Critical values (95\% Confidence Level) in parentheses.

Even if one demonstrates market integration through cointegration, there could be disequilibrium in the short-run i.e., price adjustment across markets may not happen instantaneously. In may take some time for spatial price adjustments. An error correction model takes into account the adjustment of short-run and long-run disequilibrium in the markets and the time needed to eliminate disequilibria. Table-4 shows that 37 to 53 percent of disequilibrium is removed each period, i.e. one month, in Pakistan's major apple markets. This implies that economic agents take between 2 to 3 months to adjust back to the long run equilibrium. For example, in the Karachi apple market, 47 percent of the disequilibrium is removed in each period i.e., one month, while 37 percent of the disequilibrium is removed in the Peshawar apple market. However, the coefficient for the Hyderabad market suggests that 204 percent of the disequilibrium is removed in each period, which is difficult to justify. Other apple markets follow the same pattern of adjustment to shocks except the Sargodha and Gujranwala apple markets which show non-significant results. 
Table-4: Adjustment Vectors

\begin{tabular}{lccc}
\hline $\begin{array}{l}\text { Price Relationship: } \\
\text { Quetta }\end{array}$ & Coefficient & T-Value & P-Value \\
\hline Karachi & -0.47028 & -3.4913 & 0.001 \\
Hyderabad & -2.0401 & -7.9565 & 0.001 \\
Peshawar & -0.37743 & -2.9185 & 0.004 \\
Lahore & -0.53390 & -3.2153 & 0.002 \\
Faisalabad & -0.53 .39 & -3.2381 & 0.002 \\
Multan & -0.50900 & -3.0496 & 0.003 \\
Sargodha & -0.15338 & -1.3407 & 0.183 \\
Gujranwala & 0.16632 & 1.1776 & 0.241 \\
\hline
\end{tabular}

\section{Summary and Conclusions}

This paper has examined the degree of spatial market integration in the regional apple markets of Pakistan using cointegration analysis and monthly wholesale prices data from January, 1996 to December, 2005. The results indicated that these apple markets are strongly cointegrated and converge to long run equilibrium in the sense that Pakistan's apple market system is stationary in seven directions and non-stationary in two directions. In other words, seven prices can be expressed in terms of the other two prices means that prices in nine apple markets are fully cointegrated as the law of one price (LOP) holds. The pair-wise cointegration results indicate the markets are well integrated, with Quetta being the dominant market.

The study also revealed that 37 to 53 percent of the disequilibrium is removed each period in apple markets of Pakistan. This implies that following a shock to the market which causes disequilibrium, economic agents takes between 2 to 3 months to adjust back to equilibrium.

The study confirmed that market price linkages and the interrelationships among spatial markets are important in economic analysis. Inter-market price linkages and the speed of adjustment to shocks show that transaction costs have a significant impact in determining the degree of market integration in the apple markets of Pakistan. The high degree of market integration observed in this case is consistent with view that apple markets in Pakistan are quite competitive and provide little justification for government intervention designed to improve competitiveness or to enhance market efficiency. 
The results of the research show that certain markets are not well integrated with each other, and in order to achieve the goal of integration government should promote information and develop communication within markets. To accomplish better integration and integration among the markets, infrastructural facilities should be provided by the government to the targeted markets. 


\section{References}

Barret, C.B (1996), "Markets Analysis Methods: Are Our Enriched Tool Kits Well Suited to Enlivened Markets?" American Journal of Agricultural Economics, 78: 825-829.

Dickey, D.A., and M.A. Fuller (1981), "Likelihood Ratio Statistics for Autoregressive Time Series with a Unit Root," Econometrica, 49: 1057-1072.

Golettie, F., A. Raisuddin, and N. Farid (1995), "Structural Determinants of Market Integration: The Case Rice Markets in Bangladesh," Developing Economies, 33(2): 185-202.

Greene, W. H (2000), Econometric Analysis, New Jersey: Prentice-Hall, Inc.

Holden, D. and Perman, R. (1994), "Unit Roots and Cointegration for the Economist," in Rao, B. B., Cointegration for the Applied Economist, St. Martin's Press, New York.

Johansen, S. (1988), "Statistical Analysis of Cointegration of Vectors," Journal of Economic Dynamics and Control, 12: 231-254.

Koh1, S. R. L and J. N. Uh1 (1998), Marketing of Agricultural Product, Fifth Edition, Macmillan, New York.

Negassa, A., R. Meyers and E. G. Maldhin (2003), "Analyzing the Grain Market Efficiency in Developing Countries: Review of Existing Methods and Extensions to the Parity Bound Model," Market Trade and Institutions Division, Discussion Paper 63.

Pesaran, H.M. and Peraran, B. (1987), Working with Microfit 4.0: Interactive Econometric Analysis, Oxford University Press.

Ravallion, M. (1986), "Testing Market Integration," American Journal of Agricultural Economics, 68(1): (45-52)

Sims, C. A. (1980), "Macroeconomics and Reality," Econometrica, 48: 1-49.

Tahir, Z. and K. Riaz (1997), "Integration of Agricultural Commodity Market in Punjab," The Pakistan Development Review 36 (3): 241262. 